\title{
O miejscu kompetencji pragmatycznej w glottodydaktyce
}

The place of pragmatic competence within the field of foreign language teaching

\author{
Magda SERWADCZAK \\ Uniwersytet Wrocławski/ University of Wrocław \\ E-mail: magda.serwadczak@uwr.edu.pl,
}

\begin{abstract}
Providing a broad and detailed definition of pragmatic competence can be a challenging task, mainly due to an interdisciplinary character of pragmatics itself. This article discusses the main characteristics of pragmatic competence and aims at providing a detailed description of how it was perceived by linguist since it was first described. The approaches to foreign language teaching as well as the notion of fluency have transformed throughout the years and so has our perception of pragmatic competence. Rapidly growing popularity of mobile technologies, common access to information as well as the forming of a multi-cultural society make foreign language teaching face new challenges and opportunities. The article focuses on the place pragmatic competence takes in a modern-day language teaching and argues its importance in intercultural communication and achieving proficiency in foreign language.
\end{abstract}

Keywords: pragmatic competence, foreign language teaching, authentic materials, communication, pragmatics

\section{Wstęp}

Skuteczna nauka języka obcego wiąże się z opanowaniem określonego zbioru kompetencji i sprawności. Każda metoda nauczania kładzie jednak nacisk na inne elementy i zakłada inne metody pracy mające prowadzić do skutecznego poznania języka obcego. Celem niniejszego artykułu jest odpowiedź na pytanie o miejsce kompetencji pragmatycznej w dotychczasowych metodach nauczania języków obcych, a co za tym idzie, o wagę, jaką do tej pory przywiązywali dydaktycy do pracy nad tą kompetencją. Omówione zostaną najważniejsze problemy dotyczące definiowania, badania i rozwijania kompetencji pragmatycznej. W artykule przedstawiona zostanie krótka historia pojęcia, ewolucja myśli i sposobu postrzegania kompetencji pragmatycznej przez językoznawców, począwszy od pierwszej definicji L. Bachmana, a na najnowszych opracowaniach m.in. w ramach Europejskiego Systemu Opisu Kształcenia Językowego skończywszy. Poruszona zostanie również problematyka związana z umiejscowieniem kompetencji pragmatycznej wśród pozostałych kompetencji językowych oraz omówione zostaną zależności i relacje między nimi. Wreszcie zaproponowana zostanie metoda skutecznie włączająca aktywności rozwijające kompetencje pragmatyczną w proces nauki języka obcego. 


\section{Kompetencja pragmatyczna - próba ujednolicenia definicji}

Pojęcie kompetencji w kontekście języka zostało użyte po raz pierwszy przez N. Chomsky'ego w latach 60. XX wieku. Chomsky definiował kompetencję jako wiedzę, która pozwala na posługiwanie się językiem, tj. na budowanie i rozumienie zdań (A. Żurek 2006: 50). Pojęcie to miało być odpowiedzią na ukuty przez de Saussure'a termin langue, który również oznaczał znajomość danego języka, jednak przy założeniu, że język jest tworem społecznym, a nie jak twierdził Chomsky, indywidualnym (A. Żurek 2006: 49).

$\mathrm{Na}$ kompetencję językową (zwaną później również gramatyczną) N. Chomsky'ego składały się trzy elementy: syntaktyczny, semantyczny i fonologiczny. Na tej podstawie można więc założyć, że znajomość języka sprowadzałaby się do znajomości zasad składni, semantyki oraz właściwej wymowy. N. Chomsky pomija tym samym całkowicie wszelkie zmienne o charakterze społecznym, kulturowym, a także wynikające z kontekstu. (A. Barron 2003: 8, A. Żurek 2006: 50). Choć myśl Chomsky'ego w toku jego dalszej kariery naukowej uległa zmianie i przeszła długą ewolucję, to jego klasyczna interpretacja kompetencji stała się punktem wyjścia do rozważań innych językoznawców (A. Żurek 2006: 49-56).

Niepełność definicji Chomsky’ego zauważył m.in. D. Hymes (1972), który zaproponował wprowadzenie terminu kompetencji komunikacyjnej. Według D. Hymesa znajomość języka to nie tylko znajomość elementów opisywanych przez Chomsky'ego, które D. Hymes określił mianem kompetencji gramatycznej, ale także wszystkie pozostałe zmienne, które wpływają na proces porozumiewania się, np. uwarunkowania kulturowe, społeczne, wolicjonalne itp. (A. Czechowska, 2004: 13-14). $\mathrm{W}$ rozumieniu tego badacza pojęcie kompetencji komunikacyjnej jest więc nadrzędne do pojęcia kompetencji gramatycznej.

Od momentu ukucia tego terminu przez D. Hymesa, definicja kompetencji komunikacyjnej była modyfikowana i rozbudowywana przez wielu badaczy. M. Canale (1983) zaproponował podzielenie jej na cztery kompetencje składowe: gramatyczną, socjolingwistyczną, strategiczną oraz kompetencję w obrębie dyskursu. Kompetencja gramatyczna była w tym ujęciu zbliżona do tego co pierwotnie pod pojęciem kompetencji rozumiał Chomsky, kompetencja socjolingwistyczna miała obejmować umiejętność stosowania odpowiednich w danym kontekście społecznym i kulturowym środków językowych, na kompetencję strategiczną składały się umiejętności użytkowników danego języka wykorzystywane do rekompensowania braków biegłości językowej, wiedzy lub do usprawniania komunikacji i osiągania własnych celów, natomiast w skład kompetencji w obrębie dyskursu wchodziła umiejętność tworzenia tekstów pisanych i mówionych (A. Barron 2003: 9, A. Czechowska 2004: 15-16). Pojawienie się i ewolucja kompetencji komunikacyjnej mają szczególne znaczenie w kontekście omawianej w niniejszym artykule kompetencji pragmatycznej. Oba pojęcia bywają ze sobą łączone, a kompetencję pragmatyczną uznaje się często za termin podrzędny względem kompetencji komunikacyjnej.

Określenie kompetencja pragmatyczna po raz pierwszy pojawia się u L. Bachmana (1990) w ramach jego teorii komunikacyjnej zdolności językowej (communica- 
tive language ability). Pojęciem nadrzędnym jest u L. Bachmana kompetencja językowa, oznaczająca umiejętność posługiwania się językiem. Według tego badacza, na znajomość języka i umiejętność posługiwania się nim składają się dwie kompetencje podrzędne - organizacyjna oraz pragmatyczna. Każda z nich dzieli się jeszcze odpowiednio na kompetencję gramatyczną i kompetencję w obrębie tworzenia tekstów oraz na kompetencję illokucyjną i socjolingwistyczną.

Zgodnie z teorią L. Bachmana kompetencja pragmatyczna jest wiec terminem zbiorczym określającym dwie kompetencje podrzędne: illokucyjną oraz socjolingwistyczną. Kompetencja illokucyjna jest bezpośrednio związana intencjonalnym wykorzystaniem języka i realizacją określonych aktów mowy w odpowiednich kontekstach. Według L. Bachmana kompetencja illokucyjna pełni szereg funkcji: służy do komunikowania naszych obserwacji i doświadczeń w realnym świecie (ideational function), wpływania na otaczającą nas rzeczywistość poprzez stosowanie rozkazów i poleceń (manipulative function), poszerzania wiedzy i rozwiązywania problemów (heuristic function) oraz do budowania narracji i opowiadania historii (imaginative function).

Z kolei kompetencja socjolingwistyczna obejmuje umiejętność posługiwania się językiem akceptowanym w danym kontekście, kulturze czy społeczności, operowania rejestrem właściwym w danej sytuacji, a także wybierania środków językowych naturalnie i powszechnie występujących w danym języku (L. Bachman 1990: 90-98).

Teoria L. Bachmana stała się punktem wyjścia do rozważań innych naukowców nad naturą kompetencji pragmatycznej. Bazując na definicji L. Bachmana A. Barron (2003) sprowadza kompetencję pragmatyczną do ,znajomości istnienia w danym języku środków językowych pozwalających na realizowanie określonych illokucji, świadomości sekwencyjności aktów mowy i umiejętności stosowania środków językowych danego języka we właściwych dla nich kontekstach" (A. Barron 2003: 10; tłum.: M.S.).

Z kolei K. Rose (1999) opiera swoją definicję kompetencji pragmatycznej na dychotomii G. Leecha (1983), który zakładał, że pragmatyka składa się w gruncie rzeczy z dwóch elementów: pragmalingwistyki oraz socjopragmatyki. K. Rose sprowadził zatem kompetencję pragmatyczną do umiejętności wykorzystania dostępnych środków językowych (czerpanych z obszaru pragmalingwistyki) w sposób społecznie akceptowany (w obszarze socjopragmatyki) (K. Rose 1999: 2-3).

Jedną z najnowszych publikacji definiujących i stosunkowo szeroko opisujących kompetencję pragmatyczną jest Europejski System Opisu Kształcenia Językowego (ESOKJ). W ESOKJ kompetencja pragmatyczna stanowi część komunikacyjnych kompetencji językowych. W jej skład wchodzić mają dwie podkompetencje: dyskursywna oraz funkcjonalna. Kompetencja dyskursywna zakłada umiejętność porządkowania wypowiedzi i układania zdań w takiej kolejności, aby tworzyły ciąg logiczny. Chodzi tu między innymi o zachowanie ciągów przyczynowo-skutkowych, oddzielanie wątku głównego od wątków pobocznych czy umiejętność logicznego argumentowania. Autorzy Europejskiego Systemu Opisu Kształcenia Językowego zakładają również, że użytkownik języka charakteryzujący się rozwiniętą kompetencją dyskursywną będzie stosował się do zasad kooperacji P. Grice’a. Tym samym będzie dążył 
do tego, aby jego wypowiedź była zbudowana poprawnie pod względem jakościowym (czyli nie będzie mijała się z prawdą), ilościowym (będzie zawierała odpowiednią ilości informacji), relewancji (będzie na temat) oraz sposobu (będzie logicznie zbudowana, bez zbędnych zawiłości utrudniających komunikację) (D. Coste i in. 2003: 101-130). Kompetencja dyskursywna przypomina więc w swoich założeniach Bachmanowską kompetencję w obrębie tworzenia tekstów, nie zaś kompetencję pragmatyczną. L. Bachman pomija również w swojej definicji reguły konwersacyjne P. Grice'a, których przestrzeganie niełatwo jest przypisać do kompetencji innej niż pragmatyczna.

Kolejną ze składowych kompetencji pragmatycznej wg ESOKJ jest kompetencja funkcjonalna. Zakłada ona zbiór umiejętności, które przypominają te opisywane przez L. Bachmana (1990) i A. Barron (2003), czyli umiejętność realizowania określonych aktów mowy. Użytkownik języka posiadający kompetencję funkcjonalną potrafi zatem należycie wyrażać emocje (zadowolenie, niezadowolenie), chęci, życzenia, potrafi tworzyć narrację, opis czy wydawać instrukcje. Taki użytkownik języka jest również świadomy istnienia w języku schematów społecznej interakcji. Zdaje sobie więc sprawę z tego, że rozmowy odbywają się zgodnie z pewnym scenariuszem i umie według tego scenariusza postępować. Chodzi tu o świadomość, że pytanie wymaga odpowiedzi, stwierdzenie wymaga potwierdzenia lub sprzeciwu, a prośba jej przyjęcia lub odrzucenia. (D. Coste i in. 2003: 101-130).

Warto zauważyć, że zgodnie z Europejskim Systemem Opisu Kształcenia Językowego, stosowanie się do zasad grzeczności językowej nie stanowi części kompetencji pragmatycznej, a przypisuje się ją kompetencji socjolingwistycznej. Takie postrzeganie grzeczności językowej jest niezgodne z myślą niektórych językoznawców, np. M. Marcjanik (2001), która definiuje grzeczność językową jako „zbiór przyjętych w danej społeczności wzorów językowych zachowań grzecznościowych, zwyczajowo przyporządkowanym określonym sytuacjom pragmatycznym" (M. Marcjanik 2001, cyt. za A. Żurek 2008: 33). Grzeczność językową przenoszą na grunt pragmatyki także L. Leech (1983) czy P. Grice (1977). Choć autorzy ESOKJ wspominają o grzeczności językowej w kontekście społecznym i przypisują ją kompetencji socjolingwistycznej, przyznają również, że konieczność skorzystania z konwencji grzecznościowych jest często powodem złamania zasad kooperacji P. Grice’a, które z kolei stanowią zagadnienie czysto pragmatyczne (D. Coste i in. 2003: 101-130).

Jak widać po wyżej opisanych przykładach, definicja kompetencji pragmatycznej nie jest całkowicie sprecyzowana, a uznanie bądź odrzucenie niektórych jej elementów pozostaje przedmiotem badań językoznawczych. Przykład grzeczności językowej pokazuje zaś, że granice pomiędzy obszarami określonych kompetencji nie zawsze są wyraźne, a niektóre zjawiska opisywać można zarówno na gruncie pragmatycznym, jak również socjolingwistycznym bądź kulturowym.

Pod koniec 2018 roku ukazała się aktualizacja Europejskiego Systemu Opisu Kształcenia Językowego, zawierająca nowe wskaźniki biegłości językowej. W przypadku kompetencji pragmatycznej mowa jest tutaj o elastyczności, czyli o stopniu w jakim użytkownik języka jest w stanie zareagować na nowe, niespodziewane sytuacje językowe i formułować myśli na różne, zależne od sytuacji sposoby. Innym 
wskaźnikiem jest inicjatywa, czyli umiejętność przejęcia kontroli nad rozmową czy zabrania głosu w dyskusji. Następnie mowa jest o stopniu uporządkowania tekstu, m.in. zgodnie z zasadami retoryki, dzięki czemu myśli prezentowane są w sposób logiczny. Kolejnym wskaźnikiem jest koherencja i kohezja, czyli umiejętność łączenia poszczególnych elementów tekstu za pomocą odpowiednich środków językowych, zarówno na poziomie poszczególnych zdań, jak również tekstu pisanego lub mówionego jako całości. Piątym wskaźnikiem według ESOKJ jest precyzja, czyli zdolność dokładnego przekazania wszelkich niuansów znaczeniowych i wyeliminowania wieloznaczności, które prowadziłyby to utrudnienia komunikacji. Ostatnim wskaźnikiem jest płynność w mówieniu, która może być rozumiana jako zdolność do wypowiadania się bez zbędnych przerw, umiejętność samodzielnego wygłaszania dłuższych wypowiedzi czy spontaniczność.

Podsumowując - kompetencję pragmatyczną definiować można jako umiejętność wykorzystania języka w sposób funkcjonalny, tj. ze zrozumieniem i wykorzystaniem dostępnych w języku aktów mowy, przy jednoczesnym zachowaniu zasad ich sekwencyjności oraz postepowaniu zgodnym ze schematami interakcji oraz zasadami współpracy. Kompetencja pragmatyczna wyraża się również w umiejętności tworzenia spójnych tekstów, zarówno mówionych, jak i pisanych, które zbudowane są w sposób logiczny i odpowiadający kontekstowi, w którym są umieszczane oraz które opierają się na logicznej argumentacji.

\section{Miejsce kompetencji pragmatycznej w dotychczasowych metodach naucza- nia języków obcych}

Jak zauważa A. Barron (2003) zainteresowanie glottodydaktyków kompetencją pragmatyczną było wynikiem rosnącego zainteresowania kompetencją komunikacyjną, która często uważana jest za bezpośrednio związaną lub nadrzędną względem kompetencji pragmatycznej. Jednak przed pojawieniem się podejścia komunikacyjnego, w nauczaniu języków obcych dominowały inne metody. Przedstawione poniżej zestawienie opisuje jedynie kilka najpopularniejszych i najczęściej omawianych w literaturze metod nauczania. $Z$ powodu ograniczeń, jakie na autora nakłada forma artykułu, pominięto m.in. wszelkie metody niekonwencjonalne czy autorskie.

Jedną z najwcześniejszych metod nauczania języków obcych była metoda bezpośrednia. Zakładała nauczanie w sposób zbliżony do akwizycji języka pierwszego, czyli poprzez jak najszerszy kontakt z językiem docelowym, najlepiej w kraju języka docelowego i we współpracy z ojczystymi użytkownikami tego języka. Język miał więc wykształcać się w procesie naturalnego kontaktu ucznia z nauczycielem (H. Komorowska 2009: 25-36). Założenia te są stosunkowo korzystne w kontekście rozwoju kompetencji pragmatycznej, sama metoda nie jest jednak pobawiona wad. Pozostaje pytanie o możliwość stworzenia warunków autentycznej komunikacji w sytuacji zinstytucjonalizowanej nauki języka i w sytuacji, w której nie ma możliwości zapewnienia stałego kontaktu z natywnymi użytkownikami danego języka lub jego kulturą docelową. Nie należy również zapominać o różnicach pomiędzy akwizycją języka pierwszego, a nauką języka obcego, która wymaga pewnego stopnia formalizacji i systematyzacji. 
Inną, często przywoływaną metodą jest metoda gramatyczno-tłumaczeniowa, która zakładała naukę poprzez analizę i przekład tekstów oraz pojedynczych zdań. Uczono więc głównie gramatyki i ortografii, a wiele uwagi poświęcano obserwowaniu i analizowaniu występujących w tekstach (głównie pisanych) struktur gramatycznych i słownictwa (H. Komorowska 2009: 25-36). Wśród zalet tej metody wymienia się m.in. rolę tłumaczenia w przekazywaniu treści kulturowych oraz możliwość zilustrowania przejawiających się w procesie tłumaczenia różnic pomiędzy językiem źródłowym a docelowym, m.in. w zakresie składni czy słownictwa (K. Szafraniec 2012: 93-97). Pomimo pewnych zalet metodę gramatyczno-tłumaczeniową z trudem można uznać za szczególnie ukierunkowaną na rozwijanie kompetencji pragmatycznej, która zakłada użycie języka w autentycznym kontekście. Opierając się w dużej mierze na obserwacji, metoda ta nie w pełni pozwala na samodzielne wykorzystanie języka w sposób funkcjonalny przez uczących się.

Kolejną stosunkowo popularną metodą nauczania języków obcych, była metoda audiolingwalna. $\mathrm{W}$ ujęciu audiolingwalnym wiele uwagi poświęcano wykorzystaniu języka w naturalnych sytuacjach, w oparciu o wcześniej wyuczone i wielokrotnie powtarzane zwroty i wyrażenia (H. Komorowska 2009: 25-36). Kompetencja komunikacyjna miała więc stać w centrum kształcenia językowego. Poniekąd „przy okazji” rozwijać się mogła również kompetencja pragmatyczna, bo naturalne sytuacje komunikacyjne pozwalają m.in. na wyuczenie schematów interakcji czy stosowania poszczególnych aktów mowy. Metoda audiolingwalna spotkała się jednak z krytyką, zauważono m.in., że język nie ma charakteru nawykowego - posługiwanie się nim musi więc zakładać umiejętność samodzielnego tworzenia nowych zdań oraz innowację (P. Castagnaro 2006: 519-520). Wyuczanie się stałych formułek i ich powtarzanie, nawet w ramach autentycznej lub niemalże autentycznej komunikacji nie będzie więc pozwalało na swobodne, spontaniczne wykorzystanie języka, a co za tym idzie, także na prawidłowy rozwój kompetencji pragmatycznej. Użytkownik języka posiadający tę kompetencję powinien przecież być w stanie precyzyjnie wykorzystywać język do określonych celów funkcjonalnych, a nie będzie to możliwe, jeśli posiadał będzie jedynie ograniczony wachlarz stałych zwrotów i konstrukcji językowych.

Inną metodą jest podejście komunikacyjne, zakładające że celem nauki języka nie jest poznanie i zgłębienie języka jako takiego, ale pozyskanie pewnego środka służącego do realizacji naszych pozajęzykowych celów komunikacyjnych. Także to podejście z czasem straciło na popularności i spotkało z pewną krytyką. Głównymi zarzutami kierowanymi w stronę podejścia komunikacyjnego są: pominięcie kontekstu, w którym komunikacja się odbywa, niemożność wykreowania autentycznych warunków komunikacji w szkolnych realiach oraz powierzchowne traktowanie zagadnień gramatycznych. (W. Piegzik 2004: 3-4, M. Białek 2015: 18-23, S. Bax 2002: 278283). W odniesieniu do nauczania kompetencji pragmatycznej największym problemem zdaje się jednak być pominięcie kontekstu komunikacyjnego. Język, z jakim spotykają się uczniowie w klasie ma charakter neutralny, pozbawiony jest cech indywidualnych. W naturalnych sytuacjach komunikacyjnych użytkownik języka różnicuje styl i budowę swojej wypowiedzi w zależności od okoliczności, rozmówcy czy oczekiwanego rezultatu. Inaczej wygląda więc rozmowa z kolegą lub koleżanką 
z pracy, inaczej z żoną lub mężem i jeszcze inaczej z przełożonym. Zakładając, że w kontekście pragmatycznym, nauka języka obcego ma umożliwiać skuteczną interakcję w różnych sytuacjach komunikacyjnych, ta metoda nie będzie całkowicie efektywnie pełniła swojej funkcji.

Obecnie największą popularnością cieszy się podejście eklektyczne, czerpiące ze wszystkich pozostałych. Zakłada ono m.in. częste wykorzystanie materiałów autentycznych, zapewnienie uczącym się regularnego kontaktu z językiem docelowym i umożliwienie recepcji tego języka. Pozwala również na dużą swobodę w doborze metod pracy, dzięki czemu proces nauczania języka staje się jak najbardziej zindywidualizowany i dopasowany do potrzeb ucznia (T. Konderak 2017: 203-204). Można więc założyć, że w ramach metody eklektycznej, której granice i zasady pozostają elastyczne i pozwalają nauczycielowi na dużą swobodę, sposób i intensywność pracy nad kompetencją pragmatyczną pozostanie w gestii nauczyciela. Zgodnie z duchem eklektyzmu, kompetencji pragmatycznej nie powinno poświęcać się ani mniej ani więcej uwagi niż pozostałym kompetencjom - chodzi tu przecież o jak najbardziej wszechstronny i zindywidualizowany rozwój językowy. Analizując miejsce kompetencji pragmatycznej w dotychczasowych metodach nauczania języków obcych można zauważyć, że zajmowała ona raczej peryferyjne miejsce lub była niemalże całkowicie pomijana (np. w ujęciu gramatyczno-tłumaczeniowym). Jeśli była zaś uwzględniana w procesie dydaktycznym, często działo się to kosztem innych kompetencji, a sama metoda nauczania nie pozbawiona była wad (mowa tutaj np. o metodzie bezpośredniej). W metodzie eklektycznej można więc dopatrywać się szansy nie tylko na wyeliminowanie wyżej wymienionych problemów występujących w poprzednich metodach, ale również na należyte włączenie aktywności i ćwiczeń rozwijających kompetencję pragmatyczną w proces nauki języka. W tym kontekście pozostaje więc odpowiedzieć na pytanie w jaki sposób kompetencję pragmatyczną należałoby rozwijać oraz jakie metody i ćwiczenia będą w jej przypadku najskuteczniejsze.

\section{Rozwijanie kompetencji pragmatycznej w praktyce}

Wychodząc z założenia, że kompetencja pragmatyczna może być definiowana jako umiejętność funkcjonalnego użycia języka oraz faktycznego zastosowania go (poprzez tworzenie logicznie zbudowanych tekstów mówionych i pisanych) w danym kontekście, można stwierdzić, że pozytywny wpływ na jej rozwijanie będzie miała częsta ekspozycja uczącego się na autentyczną komunikację w języku docelowym. W przypadku kursów językowych odbywających się w kraju języka docelowego nie stanowi to problemu. Inaczej jest jednak w warunkach edukacji przebiegającej w kraju, gdzie język docelowy jest językiem obcym, np. nauczając języka niderlandzkiego w Polsce.

K. Bardovi-Harlig i Z. Dörnyei (1998, cyt. za K. Rose/ G. Kasper 2001: 61) podkreślają związek pomiędzy nauczaniem języka w kraju docelowym, a rozwojem kompetencji pragmatycznej. Zauważają, że studenci uczący się języka obcego w kraju docelowym są bardziej świadomi i wrażliwi na błędy pragmatyczne niż gramatyczne, podczas gdy osoby uczące się języka obcego za granicą mają znacznie większą świadomość poprawności gramatycznej niż pragmatycznej. 
Problem z ekspozycją na autentyczne sytuacje komunikacyjne w warunkach nauki języka obcego poza granicami kraju docelowego zauważa m.in. K. Bardovi-Harling (1996), która podkreśla, że kluczowy wpływ na rozwój kompetencji pragmatycznej w warunkach zinstytucjonalizowanej nauki języka obcego mają treści językowe, na których podstawie przebiega nauka języka. Treści zasłyszane bądź przeczytane w czasie zajęć są często jedyną próbką języka, z którą styczność mają uczniowie. Problemem w kontekście pragmatycznym okazuje się nieprzystosowanie tej próbki do warunków autentycznej komunikacji. K. Bardovi-Harling zauważa, że problem ten występuje na trzech różnych poziomach: $\mathrm{z}$ jednej strony uczniowie nie mają styczności $\mathrm{z}$ treściami poprawnymi pod kątem pragmatycznym, $\mathrm{z}$ drugiej strony jeśli $\mathrm{z}$ takimi treściami się stykają, to pochodzą one ze źródeł, których uczniowie nie uznają za istotne, lub wreszcie nie rozpoznają odpowiednich treści ponieważ brakuje im świadomości pragmatycznej lub gramatycznej. W ramach swoich badań K. Badrovi-Harling przeanalizowała podręczniki do nauki języka angielskiego. Zbadała m.in. znajdujące się w nich dialogi, szczególnie pod kątem fraz zamykających rozmowę. Badania wykazały, że w większości przypadków, frazy te są całkowicie pomijane, a przytaczane w podręczniku dialogi urywają się zaraz po zrealizowaniu tematu rozmowy. Tym samym dialogi te nie stanowią przykładu autentycznej konwersacji i nie mogą zostać uznane za model prawidłowy pod względem pragmatycznym (K. Bardovi-Harling 1996: 23-36). W wyniku analizy porównawczej aktów mowy realizowanych za pomocą dialogów w podręcznikach z korpusem zawierającym autentyczne wypowiedzi rodzimych użytkowników języka realizujących te same akty mowy, okazało się, że w większości przypadków treść podręczników całkowicie odbiega od rzeczywistej komunikacji. (K. Bardovi-Harling 1996: 23-36).

Opisywane przez K. Bardovi-Harling problemy mogą zostać wyeliminowane, jeśli część materiałów dydaktycznych zostałaby zastąpiona materiałami autentycznymi, czyli stworzonymi przez rodzimych użytkowników danego języka, w odpowiedzi na ich realne potrzeby komunikacyjne (M. Smuk 2013: 76-80). Stanowią one wierne odzwierciedlenie różnorodności języka, ilustrując tym samym bogactwo jego stylów, rejestrów czy struktur. Dzięki głębokiemu osadzeniu w kulturze kraju docelowego oraz różnorodności pod względem tematycznym, materiały autentyczne przyczyniają się również do rozwijania kompetencji pozajęzykowych. (M. Smuk 2013: 76-80).

Pozytywny wpływ materiałów autentycznych na rozwijanie kompetencji pragmatycznej podkreśla także M. Kaliska (2018), która zauważa, że ich wykorzystanie, szczególnie w połączeniu z odpowiednią instrukcją pragmatyczną (pragmatic instruction), może w kontekście różnic pragmatycznych znacznie poprawić wrażliwość językową uczących się.

Fora internetowe, media społecznościowe czy chaty stanowią według M. Kaliskiej bogate źródło materiałów autentycznych, a pojawiające się w nich teksty przejawiają cechy zarówno języka mówionego, jak i pisanego i mogą mieć pozytywny wpływ na rozwój kompetencji pragmatycznej. Z jednej strony kontakt z materiałami autentycznymi pozwala na zaobserwowanie przebiegu autentycznej komunikacji, $\mathrm{z}$ drugiej wykonywanie praktycznych ćwiczeń w oparciu o takie materiały wymaga 
samodzielnego, spontanicznego i funkcjonalnego użycia języka (M. Kaliska 2018: 78).

C. Kramsch (1993) zauważa z kolei, że materiały autentyczne, a w szczególności autentyczne materiały audiowizualne są doskonałym nośnikiem informacji kulturowych i kontekstowych. Dzięki temu stanowią poprawny pragmatycznie model językowy. Ponadto postępujący rozwój technologii pozwala na wykorzystywane ich na różne sposoby, w zależności od poziomu zaawansowania uczących się. Filmy wyświetlane mogą być z napisami lub bez, w całości lub we fragmentach, z przerwami lub bez, w wersji standardowej lub w zwolnionym tempie. Dzięki temu uczniowie mogą zapoznawać się z nim w sposób, który najbardziej im odpowiada i jest dla nich najkorzystniejszy (C. Kramsch 1993: 177-202).

W świetle powyższego można stwierdzić, że rozwijanie kompetencji pragmatycznej w warunkach zinstytucjonalizowanej nauki wymaga nie tylko zastosowania materiałów autentycznych, ale również odpowiedniego ich przygotowania. Prymarnym celem dydaktyków powinno być w kontekście pragmatycznym podniesienie świadomości uczniów w zakresie różnic pragmatycznych, a następnie wyposażenie ich w narzędzia, które pozwolą na precyzyjną komunikację pomimo ich występowania.

\section{Bibliografia}

Bachman, L. (1990), Fundamental Considerations in Language Testing. Oxford.

Bardovi-Harling, K. (1996), Pragmatics and Language Teaching: Bringing Pragmatics and Pedagogy Together, (w:) L. Bouton (red.), Pragmatics and Language Learning. Monograph Series Volume 7. Urbana-Champaign, 21-39.

Bardovi-Harling, K./ Z. Dörnyei (1998), Do Language Learners Recognize Pragmatic Violations? Pragmatic versus Grammatical Awareness in Instructed L2 Learning, (w:) „TESOL Quarterly” 32, 233-262.

Barron, A. (2003), Acquisition in Interlanguage Pragmatics: Learning how to Do Things with Words in a Study Abroad Context. Amsterdam/ Philadelphia.

Bax, S. (2002), The end of CLT. A context approach to language teaching, (w:) „ELT Journal" 3, 278-287.

Białek, M. (2015), Podejście komunikacyjne i zakres jego realizacji w nauczaniu języków obcych, (w:) ,Lingwistyka Stosowana” 3, 17-29.

Canale, M. (1983), From Communicative Competence to Communicative Language Pedagogy, (w:) J. Richards/ R. Schmidt (red.), Language and Communication. Londyn/Nowy Jork, 2-27.

Castagnaro, P. (2006), Audiolingual Method and Behaviorism: From Misunderstanding to Myth, (w:) ,Applied Linguistics” 3, 519-526.

Coste, D./ B. North/ J. Sheils i in. (2003), Europejski System Opisu Kształcenia Językowego: uczenie się, nauczanie, ocenianie. Warszawa.

Czechowska, A. (2004), Kompetencja komunikacyjna w glottodydaktyce, (w:) A. Dąbrowska (red.), Wrocławska dyskusja o języku polskim. Wrocław, 13-19. 
Grice, P. (1977), Logika i konwersacja, (w:) J. Bartmiński (red.), Programy dydaktyczne bibliografia etykieta językowa. Lublin, 75-90.

Kaliska, M. (2018), Developing pragmatic competence through language digital resources, (w:) R. Biasini/ A. Proudfoot (red.), Using digital resources to enhance language learning - case studies in Italian. Voillans, 5-15.

Kasper, G. (1992), Pragmatic transfer, (w:) „Second Language Research” 8, 203231.

Kim, H. (2017), The effects of pragmatic instruction on the pragmatic awareness and production of Korean university students, (w:) „Indonesian Journal of Applied Linguistics" 2, 371-380.

Komorowska, H. (2009), Metodyka nauczania języków obcych. Warszawa.

Konderak, T. (2017), Koncepcje, podejścia i metody nauczania języków obcych dzieci, (w:) „Edukacja Elementarna w Teorii i Praktyce” 3, 189-206.

Kramsch, C. (1993), Context and Culture in Language Teaching. Oxford.

Leech, G. (1983), Principles of Pragmatics. London/New York.

Marcjanik, M. (2001), W kręgu grzeczności. Wybór prac z zakresu polskiej etykiety językowej. Kielce.

Piegzik, W. (2004), Wspótczesny eklektyzm glottodydaktyczny - rozważania nad metoda, (w:) ,Języki obce w szkole" 3, 3-7.

Rose, K. (1999), Teachers and students learning about requests in Hong Kong, (w:) E. Hinkel (red.), Culture in Second Language Teaching and Learning. New York, 167-180.

Rose, K./ G. Kasper (2001), Pragmatics and Language Teaching. Cambridge.

Smuk, M. (2013), Definicje i redefinicje materiatów autentycznych - perspektywa podmiotowa ucznia, (w:) ,Języki obce w szkole” 1, 76-81.

Szafraniec, K. (2012), Metoda gramatyczno-tlumaczeniowa oraz elementy przekładu w glottodydaktyce polonistycznej, (w:) G. Zarzycka (red.), Glottodydaktyka polonistyczna a lingwistyka kulturowa. Łódź, 93-103.

Żurek, A. (2006), Model „,kompetencji językowej” Noama Chomsky'ego, (w:) „Rozprawy Komisji Językowej Wrocławskiego Towarzystwa Naukowego" 1, 49-56.

Żurek, A. (2008), Teorie grzeczności językowej (w:) „Acta Universitatis Wratislaviensis" $7,33-43$. 